\title{
Clinical implementation of genome editing for correction of human diseases
}

\author{
Marina O. Popova, Kirill V. Lepik, Vladislav S. Sergeev, Alena I. Shakirova, Alisa Y. Potter, Albert R. Muslimov, \\ Ildar M. Barkhatov, Boris V. Afanasyev \\ Raisa Gorbacheva Memorial Research Institute of Children’s Oncology, Hematology and Transplantation, The First St. Petersburg \\ Pavlov State Medical University, St. Petersburg, Russia
}

Dr. Marina O. Popova, PhD, R. Gorbacheva Memorial Research Institute of Children's Oncology, Hematology and Transplantation, The First Pavlov State Medical University of St. Petersburg, Russia, 12 Roentgen St., 197022, St. Petersburg, Russia
Phone: +7 (812) 233-29-25 (office), +7 (911) 711-39-77 (mobile)

E-mail: marina.popova.spb@gmail.com

\section{Summary}

Genome editing is a breakthrough technology which consists of the process of precise modifications introduction into the genome of any organism. This scientific breakthrough provides a powerful tool for the errors correction in the nucleotide sequence of DNA. The development of the genome editing has inverted the concept of an available target for the therapeutic correction. The opportunity of highly precise and safe entering of single- and double-stranded breaks into the human DNA followed by natural DNA repair mechanisms has changed current approaches of the gene therapy and opened up new horizons in the treatment of numerous diseases. Genome editing is being developed to treat not only monogenic diseases but also infectious diseases and cancer. In the current review, we discuss the therapeutic application of genome editing.

\section{Keywords}

Genome editing, hematopoietic stem cells, ZFN, TALEN, CRISPR-Cas9, hematopoietic stem cell transplantation, HSCT, HIV, inherited diseases, monogenic diseases, cancer, hematological malignancies.

\section{Introduction}

Novel achievements in fundamental molecular biology have expanded and deepened our knowledge on the wide variety diseases molecular pathogenesis and created new tools aimed at the correction of identified pathogenic factors. The development of genome editing has changed the concept of available target for therapeutic correction. Introduction of techniques for highly precise and safe introduction of double-stranded breaks in human DNA followed by natural DNA repair mechanisms has changed current approaches to gene therapy and opens new horizons in the treatment of numerous diseases, including cancer.

It is known that there are at least 10000 human diseases caused by single gene mutations (monogenic diseases). Due to the wide use of next-generation sequencing, the number of detectable monogenic diseases tends to increase [10]. In despite of the monogenic diseases rarity, they affect over 400 million people worldwide. For some patients allogeneic hematopoietic stem cell transplantation (allo-HSCT) may be applicable to cure their genetic disease, but the majority of patients are incurable now. Genome editing for the treatment of monogenic diseases is a conceptually simple approach (genome editing can be used to correct the underlying genetic aberrations), but its basic potential power focused on the mechanism providing more than merely modifying of the causative mutation. Genome editing is a method that can make more sophisticated and nuanced genomic changes, which can be used to cure more common diseases or to modify their course [22].

\section{Genome editing in human: how does it work}

There are different tools developed for the genome editing. The most popular among them are Zinc-finger Nucleases (ZFN), Transcription Activator-Like Effector Nucleases (TALEN), as well as Clustered Regulatory Interspaced Short Palindromic Repeats (CRISPR/Cas9) systems. These systems are common in their structural features which include a specific DNA-binding segments and nuclease domain. 
The main principle of genome editing is specific recognition of a target locus, based on genomic sequence authenticity with highly precised introduction of DNA breaks in the required genome site. Using artificially produced DNA sequences, we can direct our molecular instruments to any DNA locus thus selecting a target to correct. By nuclease domain activation in the case of nucleases listed above, a double-stranded break is introduced to genomic DNA of the target cell. The targeted DNA break generally affects a neighbor segment of the DNA-binding domain. Such endonuclease-based procedure causes stable, heritable changes of the target gene sequence and/or its expression in the cell. After introducing double-stranded breaks, one may give a rise to short insertions or deletions (indels) in the gene causing its functional inactivation (a 'knockout' procedure) due to the genetic code frameshift. Such inaccurate repair of the DNA occurs in the absence of homologous donor DNA and is reffered as non-homologous DNA end joining (NHEJ). By contrary, when exploiting a proper mechanism of homology-directed repair (HDR) of a double-stranded break, which reproduces precise copies of sister chromatids or exogenous DNA template, we are able to overwrite, i.e., to precisely introduce a correct nucleotide sequence or integrate a new gene (transgene), with high degree of accuracy. For this purpose, we need to bring a donor DNA segment for its insertion to the site of double-stranded breakage. Such template will be replicated during the homologous breakage repair.

Among the most important principles of the site-specific nuclease application the safety holds a specific place. In particular, the safety can be obtained, for example, by the transient expression of gene editing system components after the nuclease-encoding mRNA transfection. Once the mRNA is translated and the nuclease protein maturated, the RNA rapidly and entirely degraded within the cell In a natural way. In this respect, the only challenge is to deliver a nuclease-encoding genetic construct to the target cells. A simple and safe solution is to use viral vectors that are unable to integrate into the human genome, being intended only for transportation of viral genetic construct to the cell. However, there are some limitations, due to the size of this construct and cell tropism of transporter viruses and due to their toxicity for certain cell and tissue types. However, this way is plausible and practically applicable for in vivo administration. Physical methods of the DNA transfection represent a simpler and safer approach, i.e., phagocytosis, lipofection, electropo-

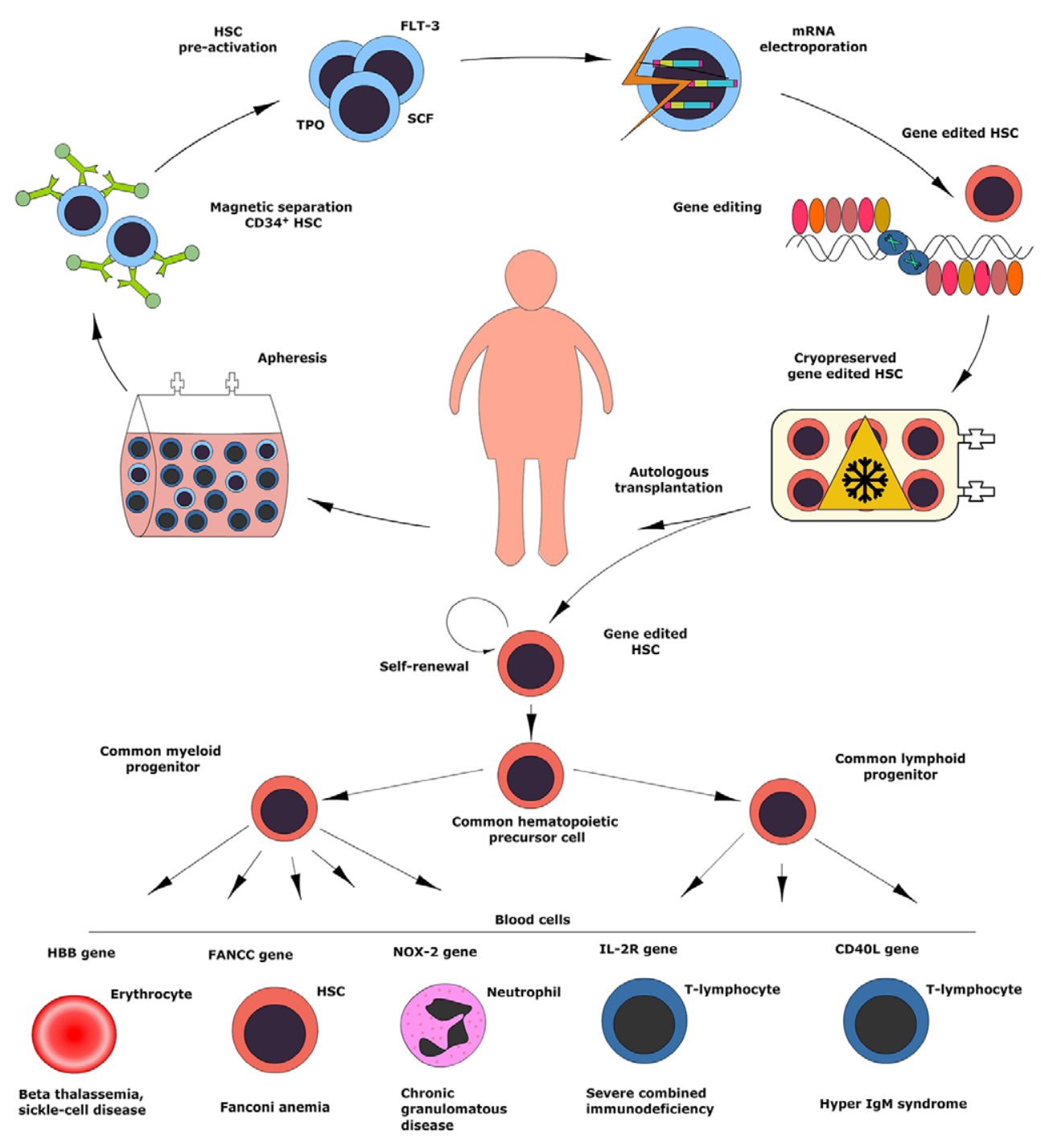

Figure 1. Flow-chart of genome editing procedure for treatment of monogenic diseases based on hematopoietic stem cell transplantation (adapted from [11]). 
ration, which also have their practical limitations. Clinically aimed genome editing in humans was applied for isolated cells taken from the human body and, after appropriate manipulations, returned to the host. The ex vivo protocols presume high enrichment of a distinct cell population, such as lymphocytes and hematopoietic stem cells (HSCs). The lymphocytes are obtained from peripheral blood, whereas stem cells could be enriched from bone marrow, umbilical blood, or peripheral blood from mobilized donors. The hematopoietic stem cell isolation is accomplished by additional separation procedures, in order to get a pure progenitor population. Cryoconservation of the cells with good viability followed by their intravenous infusion is widely used in the routine clinical practice over 50 years of the bone marrow transplantation. Hematopoietic stem cells are one of the most popular and promising target for gene therapy protocols, due to their tissue-specific homing, ability for differentiation and production of various blood cells, as well as broad clinical experience with their transplantation [11] (Fig. 1).

\section{Potential therapeutic applications of genome editing}

Discussion on therapeutic applications of the genome editing in human could be chronologically divided into three parts, i.e., current fields of genome editing, close future of the methodology, and its long-range prospective in the human diseases therapy.

State of the art. HIV treatment is a leading field among different approaches to therapeutic usage of genome editing, with six already registered clinical trials (all of them are based on ZFN platform), and a number of pre-clinical and experimental data. A clinical case of a 'Berlin patient' proved to be a countdown point: an allogeneic HSC transplant to the HIV-infected patient with acute leukemia from a donor homozygous for CCR5delta32 mutation caused cure from both hematological malignancy and HIV infection [8,9]. People with naturally occurred mutation of both CCR5 alleles are non-susceptible to HIV infection. Unfortunately, the CCR5 delta32 homozygotes make $<1 \%$ of Caucasian population, minimizing chances for finding an HLA-compatible donor with such a genetic defect [13,17]. Moreover, allogeneic HSCT is not an obligatory indication for HIV infection treatment, due to a sufficient procedure-related mortality. It is possible for only a group of $\mathrm{HIV}$-associated complications such as hematological malignances.

Meanwhile, this successful transplantation has confirmed a critical significance of CCR5 for primary infection and development of the HIV-associated disease, thus starting a new path of clinical research. Therefore, first experience of genome editing in humans was obtained in patients suffering from HIV. These experiments became able due to wellknown target gene, i.e., CCR5 that should be knocked out, thus simulating a known mutation causing HIV resistance. Similarly, the target $\mathrm{T}$ lymphocytes were selected because this cell population is a main host for HIV. Critical decrease of CD4+ T cells in humans is an evident reason for morbidity and mortality in HIV patients. Moreover, novel modalities are required for HIV treatment, due to high social significance of this infection.

A private company Sangamo Biosciences is now leading in ZFN-directed genome editing of T lymphocytes and HSCs. Higher transfection efficiency $(>50 \%)$ and rare off-target gene modification were demonstrated during pre-clinical studies of CCR5 knockout in T cells and hematopoietic stem cells. Modified HSC were transplanted to humanized NSG mice and showed their ability for a normal hematopoiesis recovery. Moreover, upon HIV infection of transplanted animals, a selective advantage in survival was noted for the modified cells, as well as HIV resistance of T cell populations and decreased viral load in the animals. $[6,11]$. Sangamo has initiated several clinical trials with this technology, including those using HSCT following a conditioning regimen. As of today, over 80 patients with HIV are enrolled into clinical studies with infusion of the 'edited' human T cells and withdrawal of HAART. Results of $2^{\text {nd }}$ phase will be published in the near future.

Other gene editing systems are also actively used for CCR5 knockout. For example, highly effective CCR 5 modification was demonstrated for human T lymphocytes using TALENbased approach $[18,19]$. Preliminary results from a joint research group of the First Palvov State Medical University of St. Petersburg and Hamburg University have shown 40 per cent efficiency for the CCR5 gene modification using CCR5Uco-TALEN system (on behalf of CIC725, unpublished data). Similar results of CCR5 gene knockout by means of CRISPR/Cas9 enzyme system have been published, where the $27 \%$ efficiency in hematopoietic stem cells was observed, with preserved viability, proliferative and differentiation capacity of the cells. Interestingly, in silico estimation predicted a significant number of homologous CCR5 sites with highrate off-target effects. However, their real occurrence proved to be as low as $0.6 \%$ [16].

Close future. Currently, we are waiting for launching several clinical protocols with genome-edited cells. All of them concern treatment of monogenic diseases, due to presence of distinct target gene loci to be corrected, and because of well-designed HSC transplantation method.

According to WHO, thousands of inherited monogenic disorders are known at the present time. Despite extreme rarity of distinct conditions, a summary prevalence of the monogenic disorders is up to $1 \%$ of total birth rates, i.e., hundreds of thousands new cases each year and the allogeneic HSCT is the one of potentially curative approach to the therapy of some types of these diseases. Due to the problems with HSC genome editing, most appropriate clinical protocols are at the stage of early pre-clinical and experimental studies with both cellular and animal models. At a longer range, these experiments should increase the gene editing efficiency to required clinical applications, aiming for safe and radical treatment of human inherited diseases [11].

Primary immune deficiencies (PID) could represent a good example of gene therapy implementations. Severe combined immune deficiencies (SCID) represent the most significant patient group. X-SCID is the most common genetic form 
of this disorder, caused by interleukin- $2 \gamma$ receptor (IL2RG) gene mutations. Several research groups have successfully used a ZFN system for induction of HDR in the IL2RG locus in different human cell types including HSCs and embryonic stem cells $[4,14]$. E.g., a copy of IL2RG was integrated into the HSC genome by means of ZFN nucleases. Integration efficiency was about $6 \%$ for ILRG2-containing cassette, showing only negligible off-target effects. Following grafting of the modified cells into a murine NSG model, a full-scale recovery of hemopoiesis with multi-lineage differentiation of immune populations were detected,. In spite of low integration efficiency of the functional gene cassette, the workers point to a selective advantage of genetically modified blood progenitors, along with reconstitution of the IL2RG function. Safety of the protocol is even increased, due to absence of special HSCT conditioning in this group of patients with immunodeficiencies [4].

Chronic granulomatous disease (CGD) is another important clinical form of PID. It is characterized by deficient synthesis of reactive oxygen species (ROS) in phagocytic cells due to NOX2 gene mutation. Successful CGD gene correction by means of retroviral gene therapy was overshadowed by evident proto-oncogene activation followed by their clonal selection. An attempt of controlled gp91phox transgene integration to a safe AAVS1 region, using induced pluripotent stem cells (iPSCs) obtained from the patient's HSCs was undertaken. The study has demonstrated an increased gp91phox mRNA levels in iPSCs subjected to genome editing, with subsequent differentiation to functional granulocytes with restored ROS production. Virtually all the modified cell clones contained a gp91phox cassette in AAVS1 locus. However, ca. $50 \%$ of them exhibited other integration sites. The study has shown an increased total efficiency and bi-allelic TALEN-induced modification (60\%) as compared to $48 \%$ with ZFN system [3]. Now more safe self-inactivating RV vectors (SIN-gRV) are in Phase I/II clinical trials for PIDs. They show comparable efficiency and the absence of events related to clonal expansion $[1,26]$.

Hyper-IgM syndrome is another disorder from the PID group. A recent report has demonstrated an in situ HDR insertion to CD40L in human lymphocytes using a TALEN system, thus making first step to the gene correction in human hematopoietic cells. The most important achievement was retaining of natural regulatory elements, profile and expression kinetics of the gene transduced, together with restored B cell function [7].

Hemoglobinopathies. Beta-thalassemia is a group of inheritable blood diseases caused by HBB gene defect, characterized by decreased or absent synthesis of hemoglobin beta protein chains. As of today, allo-HSCT is the only available method to treat these disorders. Some studies show that HBB genomic locus coils should be specifically and effectively modified by ZFN [27], TALEN, or CRISPR/Cas9 systems $[3,22]$. Using native patient-derived iPSCs treated with TALEN system, in situ correction of HBB gene was performed. HDR efficiency was not high for the system developed; however the HBB-integrated clones demonstrated normal karyotype, retained pluripotency and, upon induction to differentiation, produced hematopoietic progenitors able for erythropoiesis with normal beta-globin expression. Off-target activity of TALEN was not detected during the cell modification [15].

A recent study reported efficiency of CRISPR/Cas9 system for correction of $\mathrm{HBB}$ in iPSCs|: up to $57 \%$ of the clones showed modification of at least one HBB allele in experimental series, as well as minimal off-target activity [28].

Sickle-cell anemia is a widely spread inherited hemoglobin disorder caused by structural defect of hemoglobin chain (HBB mutation) that leads to abnormal HbS production. Correction of this specific defect by means of genome editing tools was also successfully demonstrated [17]. Another recent study applied ZFN system for repair of specific mutation in CD34+ cells from the patients. The given work yielded promising results, i.e., the HDR efficiency was up $18 \%$ in the CD34+ populations from sickle-cell anemia subjects. Restoration of normal $\mathrm{Hb}$ synthesis was confirmed in the gene-modified cells. Since only 10 to $30 \%$ of progenitor cell population is required for sufficient erythropoiesis, the efficiency of genome editing is close to the levels plausible for clinical usage. Therefore, an appropriate clinical protocol will be probably initiated in sooner time [5].

HSC pathology. Fanconi anemia occurs due to deficient proteins belonging to a DNA repair cluster . Quite recently, an in situ successful correction of FANCC gene was carried out in a primary culture of the patients' fibroblasts using CRISPR/Cas9 nucleases and CRISPR/Cas9 nickases followed by transformation of modified cells to iPSCs [20]. Of interest was a significant preference of nickase system for homology-directed repair (HDR), whereas classical nucleases favored NHEJ repair mechanisms. Generally, the CRISPR/Cas9 nuclease activity, if measured by cell modification, proved to be ca. $5 \%$, including a small number of cells with HDR. The given efficiency rate is much lower than the required for clinical trials. The procedure needs selection of clones with successful gene integration.

In vivo genome editing is connected with elaboration of effective gene delivery, using a safe virus-based vector. The first upcoming clinical study is scheduled and will include hemophilia $B$ treatment. A transgene of blood coagulation factor IX modified by genome editing will be introduced to genome of hepatocytes. The substitute gene, i.e., factor IX gene, is introduced to the target locus under albumin promoter, thus inducing factor IX protein synthesis by the human host liver. Albumin promoter was chosen as the safest and most synthesis-efficient segment of hepatocyte genome. The manipulations have to proceed as follows: the patient is infused intravenously with two viruses. The first virus produces zinc nucleases that incise the albumin gene, followed by effects of second virus that encodes the transgene incorporated into the genome [12]. Efficiency and safety of the method are shown at preclinical phase. An application for clinical use of this method has been considered and endorsed by the USA Food and drug administration (FDA).

Cancer immunotherapy. The most important developments in genome editing are directed to combat malignant tumors. By means of genome editing, novel mechanisms of tumor cell functioning are discovered, and tumor models are de- 
signed for pathogenetic analysis and studies of new medical drugs. So far, further breakthrough in oncology is connected with mechanistic studies of tumor avoidance from natural immune surveillance and achievements in the field of genetic engineering, i.e. production of $\mathrm{T}$ lymphocytes with chimeric antigenic receptors (CAR-T). The $\mathrm{T}$ cell modifications by means of genome editing are coupled to design of CAR-T cells. Appropriate gene editing procedures enable safe enhancement of antitumor effect. Nowadays, successful clinical use of CAR-T designed with TALEN technology was demonstrated in seven pediatric patients with acute lymphoblastic leukemia at London clinics $[23,24]$. Hence, expectations for gene editing in oncology are rather broad. In the nearest future, we can expect CAR-T cells after multiple editing (e.g., with combined changes in the genes encoding TCR, PD1 receptors and CTLC4 receptors). Clinical application of this data is possible without a delay upon discerning new tumor resistance mechanisms based on genome editing.

Prospective of human genome editing can be focused on breaking immune histocompatibility differences are extremely valuable in organ and tissue transplants field. The "edited" animals, e.g., pigs, may become versatile donors for humans taking into account their organ physiology and structure. One may imagine soon occurring farms for transgenic pigs that could be used as compatible graft donors for humans. This kind of pigs already exists and was a subject to multiple genome editing and knockout of immune surveillance genes thus making them plausible for xenogeneic transplants [25].

In summary, the mentioned preclinical studies with site-specific genome editing systems are challenged by the issues of procedure efficiency. Human immune populations and hematopoietic cells are among the most demanded cell editing targets. Low HDR efficiency appears to be an important problem for HSC modification, as well as loss of multilineage differentiation potential upon genetic manipulations, as well as low expansion rates of in vitro modified cells. Over last years, the field of genome editing has been developed very rapidly. Currently, there are several alternative recognized tools tested for genome editing which are based on site-specific nuclease effects. A number of research groups are working on the efficiency, safety and simplified design for these tools. Recent clinical studies have shown that the gene editing has already reached pharmacological level in terms of efficiency, specificity, delivery rates, and considered by appropriate regulatory institutes both in USA and Europe. Due to many years of fundamental studies, some specific genes responsible for certain genetic disorders were discovered. The nucleases that are able to precisely knockout target genes were discovered as well. The ex vivo experiments showed potential ability to use the modified cells in vivo, by means of cellular therapy and HSCT procedures.

Despite some difficulties, preclinical studies of genome editing are bringing medical science to a new level. Clinical implications of genome editing based on transplantation of distinct cell populations (e.g., HSCs) are quite promising and potentially successful.

\section{Acknowledgements}

We would like to thank all clinical and laboratory staff of R. Gorbacheva Memorial Research Institute of Children's Oncology, Hematology and Transplantation at the First Pavlov State Medical University of St. Petersburg. We also are grateful for useful support and cooperation in the field of hematopoietic stem cell research to Prof. Gerard Wagemaker; to Prof. Boris Fehse for cooperation in genome editing research; as well as to Prof. Fyodor D. Urnov for personal communications in the field of genome editing. We would like to express our sincere gratitude to Prof. Alexey B. Chuhlovin for advices in writing of the article, and Dr. Olga Ponomarenko for assistance and consulting.

\section{Conflicts of interest}

No conflict interests are declared.

\section{References}

1. Booth C., Gaspar H.B., Thrasher A.J. Treating Immunodeficiency through HSC Gene Therapy. Trends Mol. Med. 2016;22:317-327. doi: 10.1016/j.molmed.2016.02.002

2. Cradick TJ, Fine EJ, Antico CJ, Bao G. CRISPR/Cas9 systems targeting $\beta$-globin and CCR 5 genes have substantial off-target activity. Nucleic Acids Res. 2013;41:9584-9592

3. Dreyer AK, Hoffmann D, Lachmann N, Ackermann M, Steinemann D, Timm B, Siler U,Reichenbach J, Grez M, Moritz T, et al. TALEN-mediated functional correction of $\mathrm{X}$-linked chronic granulomatous disease in patient-derived induced pluripotent stem cells. Biomaterials 2015;69:191200. doi: 10.1016/j.biomaterials.2015.07.057.

4. Genovese P, Schiroli G, Escobar G, Targeted genome editing in human repopulating haematopoietic stem cells Nature. 2014 Jun 12;510(7504):235-40. doi: 10.1038/nature13420. Epub 2014 May 28.

5. Hoban MD, Cost GJ, Mendel MC, et al. Correction of the sickle cell disease mutation in human hematopoietic stem/ progenitor cells. Blood. 2015;125(17):2597-2604.Hoban MD, Cost GJ, Mendel MC, et al. Correction of the sickle cell disease mutation in human hematopoietic stem/progenitor cells. Blood. 2015;125(17):2597-2604.

6. Holt N, Wang J, Kim K, Friedman G, Wang X, Taupin V, et al. Human hematopoietic stem/progenitor cells modified by zinc-finger nucleases targeted to CCR 5 control HIV-1 in vivo. Nat Biotechnol (2010) 28(8):839-47.10.1038/nbt.1663

7. Hubbard, N., Hagin, D., Sommer, K., Song, Y., Khan, I., Clough, C., Ochs, H. D., Rawlings, D. J., Scharenberg, A. M., \& Torgerson, T. R. (2016). Targeted gene editing restores regulated CD40L function in X-linked hyper-IgM syndrome. Blood, 127(21), 2513-2522. Accessed March 20, 2017. DOI: 10.1182/blood-2015-11-683235

8. Hütter G, Nowak D, Mossner M et al. Long-term control of HIV by CCR 5 Delta32/Delta32 stem-cell transplantation. N Engl J Med 2009; 360:692-8 
9. Hütter G, Thiel E. Allogeneic transplantation of CCR5 deficient progenitor cells in a patient with HIV infection an update after 3 years and the search for patient no. 2. AIDS 2011; 25:273-4.

10. Johnston JJ, Lewis KL, Ng D, Singh LN, Wynter J, Brewer $\mathrm{C}$, et al. Individualized iterative phenotyping for genome-wide analysis of loss-of-function mutations. Am J Hum Genet. 2015;96:913-25.

11. Lepik, K.V., Popova, M.O., Shakirova, A.I., Sergeev, V.S., Potter, A.Y., Barkhatov, I.M., Fehse, B., Afanasyev, B.V. Site-specific genome editing for hematopoetic stem cells transplantation-based gene therapy approaches (2016) Genes and Cells, 11 (2), pp. 21-29.

12. Li H, Haurigot V, Doyon Y, et al. In vivo genome editing restores hemostasis in a mouse model of hemophilia. Nature. 2011;475(7355):217-221. doi:10.1038/nature10177.

13. Libert F, Cochaux P, Beckman G, et al. The CCR5- $\Delta 32$ mutation conferring protection against HIV-1 in Caucasian populations has a single and recent origin in Northeastern Europe. Hum Mol Genet 1998;7:399-406.

14. Lombardo A, Genovese P, Beausejour CM, Colleoni S, Lee YL, Kim KA, et al. Gene editing in human stem cells using zinc finger nucleases and integrase-defective lentiviral vector delivery. Nat Biotechnol (2007)25(11):1298306.10.1038/nbt1353

15. Ma N, Liao B, Zhang H, et al. Transcription activator-like effector nuclease (TALEN)-mediated gene correction in integration-free beta-thalassemia induced pluripotent stem cells. J Biol Chem. 2013;288:34671-34679.

16. Mandal PK, Ferreira LMR, Collins R, et al. Efficient ablation of genes in human hematopoietic stem and effector cells using CRISPR/Cas9. Cell stem cell. 2014;15(5):643-652. doi:10.1016/j.stem.2014.10.004.

17. Marmor M, Sheppard HW, Donnell D, et al. Homozygous and heterozygous CCR5-D32 genotypes are associated with resistance to HIV infection. JAIDS 2001;27:472-81.

18. Mock U, Hauber I, Fehse B Digital PCR to assess gene-editing frequencies mediated by designer nucleases. Nature Protocols 11, 598-615, (2016). doi:10.1038/nprot.2016.027

19. Mock U, Machowicz R, Hauber I, et al. mRNA transfection of a novel TAL effector nuclease (TALEN) facilitates efficient knockout of HIV co-receptor CCR5. Nucleic Acids Research. 2015;43(11):5560-5571. doi:10.1093/nar/gkv469.
20. Osborn MJ, Gabriel R, Webber BR, et al. Fanconi Anemia Gene Editing by the CRISPR/Cas9 System. Human Gene Therapy. 2015;26(2):114-126. doi:10.1089/hum.2014.111.

21. Patsali P, Mussolino C, Stephanou C, et al. Towards personalized gene therapy for $\beta$-thalassemia in Cyprus; Presented at: American Society for Gene and Cell Therapy 19th Annual Congress; Washington, DC. May 23, 2014. Abstract number 692. Molecular Therapy, Volume 22, S268.

22. Porteus MH. Towards a new era in medicine: therapeutic genome editing. Genome Biology. 2015;16:286. doi:10.1186/ s13059-015-0859-y.

23. Qasim, W., Amrolia, P. J., Samarasinghe, S., et al. (2015). First Clinical Application of Talen Engineered Universal CAR19 T Cells in B-ALL. Blood, 126(23), 2046. Accessed March 20, 2017.

24. Reardon S. Leukaemia success heralds wave of gene-editing therapies. One-year-old girl treated as plans to inject DNA-cutting technology directly into patients' bodies take shape. Nature 527, 146-147 (09 November 2015). doi:10.1038/ nature.2015.18737. http://www.nature.com/news/leukaemiasuccess-heralds-wave-of-gene-editing-therapies-1.18737

25. Reardon S. New life for pig-to-human transplants. Gene-editing technologies have breathed life into the languishing field of xenotransplantation. Nature 527, 152-154 (12 November 2015) doi:10.1038/527152a. http://www.nature. com/news/new-life-for-pig-to-human-transplants-1.18768

26. Touzot F, Hacein-Bey-Abina S, Fischer A, Cavazzana M. Gene therapy for inherited immunodeficiency. Expert Opin Biol Ther (2014) 14(6):789-98.10.1517/14712598.2014.895811

27. Voit RA, Hendel A, Pruett-Miller SM, Porteus MH. Nuclease-mediated gene editing by homologous recombination of the human globin locus. Nucleic Acids Res. 2014;42:13651378

28. Yang Y, Zhang X, Yi L et al. Naïve Induced Pluripotent Stem Cells Generated From $\beta$-Thalassemia Fibroblasts Allow Efficient Gene Correction With CRISPR/Cas9 Stem Cells Transl Med. 2016 Jan;5(1):8-19. doi: 10.5966/sctm.20150157 


\title{
Клиническое применение редактирования генома для лечения заболеваний человека
}

\author{
Марина О. Попова, Кирилл В. Лепик, Владислав С. Сергеев, Алена И. Шакирова, Алиса Я. Поттер, \\ Альберт Р. Муслимов, Ильдар М. Бархатов, Борис В. Афанасьев \\ НИИ детской онкологии, гематологии и трансплантологии им. Р. М. Горбачевой, Первый Санкт-Петербургский \\ Государственный Медицинский Университет им. акад. И. П. Павлова, Россия
}

\section{Резюме}

Редактирование генома - это революционная технология. Она представляет собой процесс внесения точных изменений нуклеотидной последовательности генома любого организма. Редактирование генома предоставляет мощный инструмент исправления генетических ошибок в нуклеотидной последовательности ДНК, и переворачивает концепцию доступной мишени для терапевтической коррекции. Создание высокоточного и безопасного метода для внесения одно- и двухцепочечных разрывов в ДНК человека с последующим использованием природных механизмов восстановления ДНК влияет на современные подходы к генной терапии и открывает новые горизонты в лечении многочисленных заболеваний. Редактирование генома разрабатывается для лечения моногенных заболеваний, инфекционных заболеваний и злокачественных опухолей. Данный обзор посвящен терапевтическому применению редактирования генома у человека.

\section{Ключевые слова}

Редактирование генома, гемопоэтические стволовые клетки, ZFN, TALEN, CRISPR-Cas9, трансплантация гемопоэтических стволовых клеток, ТГСК, ВИЧ, наследственные заболевания, моногенные заболевания, рак, опухоли кроветворной и лимфатической ткани. 